\title{
5 Rethinking species selection for restoration of arid shrublands
}

6

7 Francisco M. Padilla ${ }^{\mathrm{a}, *}$, Rafael Ortega ${ }^{\mathrm{b}}$, Joaquín Sánchez ${ }^{\mathrm{b}}$, Francisco I. Pugnaire ${ }^{\mathrm{a}}$

8

9 aastación Experimental de Zonas Áridas, Consejo Superior de Investigaciones

10 Científicas, General Segura 1, 04001 Almería, Spain.

11 *Corresponding author. Tel.: +34 950281045; fax: +34 950277100

12 E-mail address: fpadilla@eeza.csic.es

13

$14{ }^{\mathrm{b}}$ Serfosur, Gregorio Marañón 37, entreplanta 22, 04005, Almería, Spain.

15

16 Number of words: 4151

17

18 Running title: Species selection and restoration

19 
Restoration is playing an increasingly important role in ecology as natural

habitats become scarcer and chances to restore ecosystems damaged by human activities are more common. However, restoration of degraded Mediterranean arid ecosystems is hampered by drought and poor soils, which cause many establishment failures. To compare how species belonging to different successional stages establish in a very stressful site, we carried out a field experiment with 14 tree and shrub species differing in functional traits. After three growing seasons, mid-successional shrubs such as the leafless Ephedra fragilis and the $\mathrm{C}_{4}$ Salsola oppositifolia, or green-stemmed legumes like Coronilla juncea, Genista umbellata and Retama sphaerocarpa, showed survival

30 rates up to $93 \%$, while late-successional species like Tetraclinis articulata, Pinus

31 halepensis, Olea europaea and Pistacea lentiscus, frequently used and recommended in 32 regular restoration projects, hardly reached $55 \%$. We found that survival was highest for 33 legumes, followed by leafless species, and $\mathrm{C}_{4}$ shrubs, traits that are believed to 34 maximize resource uptake in cleared and infertile areas while reducing water losses.

35 Thus, selection of mid-successional species having such traits should be considered for 36 successful restoration. These species would increase the success of restoration 37 programs, but also would increase soil fertility, reduce soil erosion processes, and eventually facilitate establishment of other species, therefore accelerating secondary succession. We suggest a new approach for the restoration for arid shrublands in which

40 species are carefully selected based on traits that best suit the environmental conditions.

42 Keywords: Sapling survival; Arid environments; Leafless shrubs; Legumes; Functional 43 traits. 
Human impact on ecosystems is substantial and increasing, causing an enormous range of changes and direct and indirect effects. Indeed, between one third and half of

47 the Earth's surface has been altered by human activities (Vitousek, Mooney, Lubchenco \& Melillo 1997) and there is hardly any pristine area left. Ecosystems in the western Mediterranean basin are amongst those which have undergone the most intense changes in land use in the last 500 years (Puigdefábregas \& Mendizábal 1998). The expansion of crops, timber, and population growth until the beginning of the $20^{\text {th }}$ century eroded almost completely the natural vegetation in many areas, while in others grazing and logging selectively harvested trees and shrubs from woodlands. In the second half of the twentieth century, population concentration in urban areas led to the abandonment of farm life and, consequently, of practices designed to control soil losses in steep hills, such as terraces. Indeed, one of the biggest challenges of restoration ecology lies particularly on abandoned land and old fields (Cramer, Hobbs \& Standish 2008; Young 2000), as natural and seminatural habitats become scarcer and degraded territories are more common (Hobbs \& Harris 2001;

60 Prach, Bartha, Joyce, Pysek, van Diggelen et al. 2001). Often the first step in restoration is the re-establishment of the local species pool by actively planting pre-disturbance species (Palmer, Ambrose \& Poff 1997; Parker 1997). However, the success of community restoration in arid environments is especially at risk due to very stressful ecological conditions. Drought, together with high temperatures, high irradiance, grazing, and infertile soils, threaten the survival of planted saplings (García-Fayos \& Verdú 1998; Maestre, Cortina, Bautista, Bellot \&

67 Vallejo 2003). To enhance the chance of sapling survival, research has focused on developing new procedures aimed at modifying sapling allometry (Pausas, Bladé, 
Valdecantos, Seva, Fuentes et al. 2004; Pemán, Voltas \& Gil-Pelegrin 2006) and soil characteristics (Querejeta, Roldán, Albaladejo \& Castillo 1998), and protecting saplings against limiting conditions (Jiménez, Navarro, Ripoll, Bocio \& De Simón 2005; Padilla \& Pugnaire 2009). However, much less attention has been paid to how species selection and plant traits determine restoration success (but see Pywell, Bullock et al. 2003). Over the past years, land managers have preferentially used late-successional species in restoration projects, especially trees and large shrubs based on the idea that these will accelerate succession and improve ecosystem resilience (Bonet 2004). On the other hand, the use of small shrubs such as mid-successional species is still rare for unknown reasons. The pace of colonization processes and secondary succession in Mediterranean arid environments is rather slow (Bonet \& Pausas 2004; Pugnaire,

80 Luque, Armas \& Gutiérrez 2006), so we believe that introducing mid-successional, rather than late-successional species, may be more desirable for the restoration of arid shrublands for several reasons: (1) Mid-successional species are mostly more droughttolerant species with their regeneration niche usually linked to open areas (Valiente-

84 Banuet, Vital Rumebe, Verdú \& Callaway 2006); This should help to increase restoration success. (2) They tend to root deeper at the seedling stage, which is critical in dry environments (Padilla \& Pugnaire 2007); This will expedite establishment

87 allowing for earlier protection against erosion. (3) Green-stemmed, leafless shrubs have

88 a low ratio of leaf-to-total photosynthetic area, which is advantageous in dry, high

89 irradiation habitats (Valladares, Hernández, Dobarro, García-Pérez, Sanz et al. 2003).

90 (4) They facilitate the recruitment of drought-sensitive species under their canopies

91 (Padilla \& Pugnaire 2006) speeding up succession in a natural way towards a mature 92 community. 
To our knowledge, very few studies have simultaneously compared sapling

94 survival of both late and mid-successional species during the first years of establishment in arid environments (but see a first attempt in Padilla, Pugnaire, Marín, Hervás \& Ortega 2004). We compared sapling survival of both ecological groups, and we hypothesized that survival of mid-successional shrubs would be higher than that of latesuccesssional species because of their greater adaptation to cope with drought. We planted 14 tree and shrub species that potentially could be used in the restoration of Mediterranean arid shrublands in a very stressful environment in SE Spain and watered half of them in summer to look at drought effects on the survival of each species.

103 Materials and methods

104 Experimental site

The experimental area is located in the Sierra Alhamilla range (Almería, Spain, $37^{\circ} 99^{\prime} \mathrm{N}, 02^{\circ} 99^{\prime} \mathrm{W}, 650 \mathrm{~m}$ a.s.1.). Restoration of this deforested area had been attempted

107 several times in the last years resulting in complete failure because of its very low

108 rainfall and infertile soils. Here, we used this site as a representative case-study of

109 limiting arid environments. We selected two 1-ha plots on opposite, moderate slopes to

110 account for the different environmental conditions. Plant communities, soils, and slopes

$111(<20 \%)$, were very similar in both plots, differing only in aspect. There was a relatively

112 more humid, east-facing slope and a relatively drier, west-facing slope (see Appendix

113 A: Table 1). The climate is Mediterranean arid with a mean annual temperature of 17.3

$114{ }^{\circ} \mathrm{C}$, mild temperatures in winter and high temperatures in late spring and summer, and

$115282 \mathrm{~mm}$ of annual precipitation with a marked drought period from June to September.

116 Soils are loamy-sandy, calcic regosols developed over a mica-schist bedrock with very

117 low fertility and water-holding capacity. 
119 the $20^{\text {th }}$ century (National Statistics Institute, 2003). Until then, selective logging,

120 grazing and cropping eroded the woodland canopy. Sixty years later, the extant plant

121 community is a xeric scrubland dominated by species like Anthyllis cytisoides,

122 Artemisia barrelieri and Thymus hyemalis, interspersed with individuals of the larger

123 shrub Retama sphaerocarpa, annual grasses and herbs (see Appendix A: Figure 1). The

124 potential vegetation of this area is a shrubland dominated by the large shrubs Olea

125 europaea var. sylvestris, Pistacia lentiscus, Quercus coccifera, Ziziphus lotus and

126 Juniperus oxycedrus (Peinado, Alcaraz \& Martínez-Parras 1992), with dispersed Pinus

127 halepensis and Ceratonia siliqua trees. The pace of plant succession in these

128 environments is rather slow, with scant occurrences of mid-successional shrubs

129 Ephedra fragilis, Salsola spp., and the legumes Retama sphaerocarpa, Genista spp. and

130 Coronilla juncea.

Species and experimental design

We tested sapling survival of a wide range of native shrub and tree species that

134 potentially can be used in the restoration of these dry environments. We selected species

135 that usually occur in mid-successional stages as well as late-successional species. Early-

136 successional species, such as scrub, were not selected because they were already present

137 in the experimental site. Among the mid-successional species we selected the shrubs

138 Coronilla juncea L., Ephedra fragilis Desf., Genista umbellata (L’Hér.) Dum. Cours.,

139 Lycium intricatum Boiss., Retama sphaerocarpa (L.) Boiss. and Salsola oppositifolia

140 Desf. These species usually occur in open environments, and exhibit morphological and

141 physiological adaptations to cope with very dry environments; Ephedra, Coronilla,

142 Genista and Retama are green-stemmed or leafless shrubs, the latter three being 
143 legumes, and Salsola is a $\mathrm{C}_{4}$-xero-halophyte shrub. Most of them are able to root deep

144 (Padilla \& Pugnaire 2007) and establish well in very dry environments (Padilla et al.

145 2004). Late-successional species were the trees Ceratonia siliqua L., Pinus halepensis

146 Mill. and Tetraclinis articulata (Vahl) Mast., and the large shrubs Juniperus oxycedrus

147 L., Juniperus phoenicea L., Olea europaea L. var. sylvestris Brot, Pistacia lentiscus L.

148 and Ziziphus lotus (L.) Lam. These tend to occur in undisturbed areas, and under less

149 stressful conditions.

150 In January 2004, one-year-old saplings of each species, provided by local

151 nurseries and of local provenance, were transplanted to the east- and west-facing slopes,

152 in gaps previously selected at random, distant at least $3 \mathrm{~m}$ from any perennial species.

153 Before transplanting, the soil was dug up to a depth of $0.5 \mathrm{~m}$ using an auger (BT $120 \mathrm{C}$,

154 Stihl AG \& Co. KG, Germany) to increase aeration, and planted saplings were covered 155 with piled branches of the shrub Anthyllis cytisoides. These branches provided saplings

156 protection against radiation and extreme temperatures, and presumably also against

157 herbivory (Padilla \& Pugnaire 2009). To test the relative effect of drought on survival,

158 watering was supplied to half the saplings every 20 days on average (six times a year)

159 during the summers of 2004 and 2005. Water supply was discontinued in 2006 to

160 evaluate the effect of normal drought on previously irrigated saplings. Water was

161 supplied through the micro-irrigation technique (Sánchez, et al. 2004), which consisted

162 of a water tank and a network of polyethylene pipes of different diameters distributed

163 along the experimental plots that allocated water to the rooting zone of each sapling.

164 Micro-tubes, $5 \mathrm{~mm}$ in diameter and $35 \mathrm{~cm}$ in length, connected to pressure-compensate

165 drippers were buried into the soil at a depth of $25 \mathrm{~cm}$. Previous tests showed that around

166 1.5-3.0 L of water were released from each drip into the soil per watering event (J.

167 Sánchez, pers. comm.). 
environments, sapling survival was recorded before and after the summers of 2004,

173 Preliminary tests showed no significant effect of aspect on survival, so data from east

174 and west-facing plots were pooled. Cumulative survival in the field after three years was analyzed by simple binary logistic regression where survival in autumn was the detected a very significant species $\mathrm{x}$ watering interaction $\left(\chi_{13}^{2}=40.731, P<0.001\right)$, and exploratory analysis showed clear differences among species, we made separate one-

179 factor (watering) logistic regression for each species. Sample size of treatments was 15-

18047 saplings due to different mortality following transplantation. Analyses were

181 conducted with the statistical package SPSS v15.0 (SPSS Inc., Chicago, IL, USA) and 182 differences were set significant at $P<0.05$.

\section{Results}

A very rainy spring in 2004 was followed by a summer with negligible rainfall maintained survival rates above $70 \%$ without irrigation (Figure 1). On the other hand,

188 the mortality of unwatered Juniperus spp., Ceratonia, Olea, Tetraclinis and Ziziphus

189 was remarkable. In this case, watering managed to enhance sapling survival.

190 Very low rainfall characterized year 2005, which was also marked by a very dry spring and summer. In this dry year, sapling survival decreased compared with 2004, 
192 but our leguminous shrubs and the $\mathrm{C}_{4}$ Salsola showed rates above $50 \%$ even if

193 unwatered (Figure 1).

194 In autumn 2006, an average year in terms of annual and spring rainfall, saplings

195 that had been irrigated in preceding summers kept showing higher survival rates than

196 non-irrigated plants, although species like Ceratonia and Lycium suffered from the

197 overall low water availability and equalled survival of controls.

198 On the whole, survival data after three years showed that water supply during

199 summer did increase sapling performance of mid-successional species such as

200 Coronilla, Ephedra, Genista, Retama and Salsola (Figure 2), but very high survival

201 rates were reported even for unirrigated saplings of these species. They clearly survived

202 best, attaining establishment rates close to $50 \%$ without water supply, and generally

203 well above this number if watered: $93 \%$ for Genista, $83 \%$ for Retama, and $75 \%$ for

204 Ephedra.

205 Survival of late-successional species was notably lower than that of mid-

206 successional species, and in some cases survival of unirrigated, mid-successional

207 species was higher than that of irrigated, late-successional species. Water supply

208 boosted establishment rates of most late-successional species, particularly those of

209 Juniperus spp., Tetraclinis, Ziziphus, Olea and Pistacia, but these species mostly died

210 without irrigation (i.e., survival $<25 \%$ ). As an extreme case, we recorded very low

211 survival $(<10 \%)$ for irrigated Ceratonia trees, suggesting that in this species more

212 watering should be provided to secure establishment.

214 Discussion 
216 late-successional shrubs and trees. Since usually, late successional species dominate in

217 restoration programs, our data provide more evidence for critically reconsidering

218 species selection for dryland management. Indeed, Padilla et al. (2004) had already

219 showed in a very stressful site that legumes and chenopodiaceous shrubs attained high

220 survival, whereas large casualties were recorded for the traditional late-sucessional trees

221 and shrubs.

We believe that at least three suits of morpho-physiological traits might be

involved in the responses of mid-successional species. First, these species tend to

colonize disturbed, open habitats whereas late-successional species occur frequently in

less limiting sites (Peinado, Alcaraz \& Martínez-Parras 1992; Pugnaire et al. 2006). For

instance, Retama sphaerocarpa and the halophytic $\mathrm{C}_{4}$ shrub Salsola oppositifolia root

much deeper than the late-successional Pinus halepensis under very dry soil conditions

(Padilla \& Pugnaire 2007) indicating a better adaption to drier and more disturbed

habitats at least at the seedling stage. It is thus likely that these species are better suited

to cope with drier climate predicted by global change scenarios. Second, mid-

successional species having the highest survival, except Salsola, had green stems and remained leafless for most of the year. This low ratio of leaf to total photosynthetic area prevents water losses and injuries from high irradiance in high irradiation habitats.

234 Thus, leaflessness seems a trait involved in high sapling survival in arid environments.

235 In Salsola, however, the $\mathrm{C}_{4}$ photosynthetic pathway is an advantage under high

236 irradiance and temperature. Third, the best survivors were mostly leguminous shrubs.

237 Valladares, Villar Salvador et al. (2002) found that Rhizobium inoculation enhanced the early performance of Retama saplings in very poor soils, so N-fixing bacteria likely

239 favoured endurance of leguminous shrubs in these unfertile sites. 
In ecological terms, restoration of arid shrublands should not only aim to install

241 a number of desired species, but should also speed up succession and restore ecosystem

242 functioning to pre-disturbance levels (Aronson, Floret, Le Floc'h, Ovalle \& Pontanier

243 1993; Palmer et al. 1997; Parker 1997; Prach et al. 2001). In this sense, we believe that

244 using colonizers, legumes and/or leafless species in restoration of very stressful habitats

245 may contribute to ecosystem restoration in several ways.

246 Chenopodiaceous shrubs are able to successfully establish in cultivated pastures,

247 and hence have potential to develop a perennial woody canopy in the landscape in the

248 long term (Wong, Dorrough, Hirth, Morgan \& O'Brien 2007). Mid-successional species

249 establish more easily in degraded habitats that late-successional species, as their

250 regeneration niche is often linked to open areas (Valiente-Banuet et al. 2006). Thus,

better plant establishment can lead to more successful restoration, in terms of binding

252

organic matter, reducing soil erosion, and providing microsites for other species to establish.

reduce irradiance and temperature at the soil surface, thus facilitating the recruitment of more drought-sensitive species (see review in Padilla \& Pugnaire 2006). This nurse plant effect has not only been found in very harsh environments, but also in highly polluted and degraded grasslands in Central Europe between a forb and other forb species and grasses (Temperton \& Zirr 2004). Therefore, as facilitation and nurse plants

260 often play a key role in succession (Walker \& del Moral 2003), mid-successional shrubs 261 may accelerate secondary succession in a natural way (Li, Fang, Jia \& Wang 2007),

262 which is essential in ecosystem restoration (Prach et al. 2001). In addition, some shrubs 263 flower very soon after plantation (like Genista and Coronilla, pers. obs.; De Mei and Di 
264 Mauro 2006), and may accelerate succession in neighbouring areas by forming a new source of seeds.

Finally, leguminous shrubs may increase soil fertility (Pugnaire, Haase,

267 Puigdefábregas, Cueto, Clark et al. 1996; Rodríguez-Echeverría \& Pérez-Fernández

268 2005), and the improvements in the physico-chemical and biological properties of the

269 rhizosphere of these species could facilitate the establishment of new species in the

270 surrounding area, which would help revegetation of arid ecosystems (Caravaca,

271 Alguacil, Figueroa, Barea \& Roldán 2003). In addition, the use of mid-successional

272 shrubs would help restore soil fertility as these species tend to reduce erosion processes

273 (Bochet, Rubio \& Poesen 1998; De Baets, Poesen, Knapen, Barber \& Navarro 2007).

274 In conclusion, we underline a new approach in the restoration of arid sites, which

275 the ecology of the site and the appropriateness of the initial species restored play a

276 pivotal role. In this framework, species selection is a critical step that should be

277 carefully considered. Early colonizers, legumes, and leafless species should be preferred

278 to late-successsional species in arid regions. Selection of species with these traits is key

279 for successful restoration of arid ecosystems. In practical terms, using these species

280 would save an enormous amount of money and manpower as no watering would be

281 needed to ensure establishment, and enhanced survival of implanted saplings would

282 reduce costs of replanting.

284 Acknowledgements

285 We are indebt to Katja Tielbörger and two anonymous reviewers for improving 286 an earlier draft of this manuscript. Special thanks to Alejandro Moreno, Juan de Dios

287 Miranda, Pilar Sánchez, Mar Candel, Carlos Escudero and Florentino Mostaza for help

288 during field work. This project was funded by the Spanish Ministry of Education and 
Science (grants AGL2000-0159-P4-02 and CGL2004-00090/CLI). FMP was supported

290 by an I3P predoctoral fellowship (CSIC-European Social Fund).

291

292

Appendix A: Supplementary Material

293

The online version of this article contains additional supplementary data. Please

294 visit

295

296

References

297

Aronson, J., Floret, C., Le Floc'h, E., Ovalle, C., \& Pontanier, R. (1993). Restoration

298 and rehabilitation of degraded ecosystems in arid and semi-arid lands. I. A view from the South. Restoration Ecology, 1, 8-17.

Bochet, E., Rubio, J.L., \& Poesen, J. (1998). Relative efficiency of three representative matorral species in reducing water erosion at the microscale in a semi-arid climate (Valencia, Spain). Geomorphology, 23, 139-150.

Bonet, A. (2004). Secondary succession of semi-arid Mediterranean old-felds in southeastern Spain: insights for conservation and restoration of degraded lands. Journal of Arid Environments, 56, 213-233.

Bonet, A., \& Pausas, J.G. (2004). Species richness and cover along a 60-year chronosequence in old-fields of southeastern Spain. Plant Ecology, 174, 257270.

Caravaca, F., Alguacil, M.M., Figueroa, D., Barea, J.M., \& Roldán, A. (2003). Reestablishment of Retama sphaerocarpa as a target species for reclamation of soil physical and biological properties in a semi-arid Mediterranean area. Forest Ecology and Management, 182, 49-58. 
313 Cramer, V.A., Hobbs, R.J., \& Standish, R.J. (2008). What's new about old fields land abandonment and ecosystem assembly. Trends in Ecology \& Evolution, 23, 104112.

De Baets, S., Poesen, J., Knapen, A., Barber, G.G., \& Navarro, J.A. (2007). Root characteristics of representative Mediterranean plant species and their erosionreducing potential during concentrated runoff. Plant and Soil, 294, 169-183.

De Mei, M., \& Di Mauro, M. (2006). Study of some characteristic Mediterranean vegetation species best suited for renaturalization of terminal-phase municipal

Hobbs, R.J., \& Harris, J.A. (2001). Restoration Ecology: Repairing the Earth's Ecosystems in the New Millennium. Restoration Ecology, 9, 239-246.

Jiménez, M.N., Navarro, F.B., Ripoll, M.A., Bocio, I., \& De Simón, E. (2005). Effect of shelter tubes on establishment and growth of Juniperus thurifera L. environmental heterogeneity and spatiotemporal dynamics of seedling establishment in a semiarid degraded ecosystem. Ecosystems, 6, 630-643. 
337 Padilla, F.M., \& Pugnaire, F.I. (2006). The role of nurse plants in the restoration of degraded environments. Frontiers in Ecology and the Environment, 4, 196-202.

Padilla, F.M., \& Pugnaire, F.I. (2007). Rooting depth and soil moisture control Mediterranean woody seedling survival during drought. Functional Ecology, 21, 489-495.

Padilla, F.M., \& Pugnaire, F.I. (2009). Species identity and water availability determine establishment success under the canopy of Retama sphaerocarpa shrubs in a dry environment. Restoration Ecology. doi: 10.1111/j.1526-100X.2008.00460.x

Padilla, F.M., Pugnaire, F.I., Marín, R., Hervás, M., \& Ortega, R. (2004). El uso de especies arbustivas para la restauración de la cubierta vegetal en ambientes

Palmer, M.A., Ambrose, R.F., \& Poff, N.L. (1997). Ecological theory and community restoration ecology. Restoration Ecology, 5, 291-300.

Parker, V.T. (1997). The scale of successional models and restoration objectives. Restoration Ecology, 5, 301-306.

Pausas, J.G., Bladé, C., Valdecantos, A., Seva, J.P., Fuentes, D., Alloza, J.A., Vilagrosa,

Pemán, J., Voltas, J., \& Gil-Pelegrin, E. (2006). Morphological and functional variability in the root system of Quercus ilex L. subject to confinement: consequences for afforestation. Annals of Forest Science, 63, 425-430. 
Prach, K., Bartha, S., Joyce, C.B., Pysek, P., van Diggelen, R., \& Wiegleb, G. (2001). The role of spontaneous vegetation succession in ecosystem restoration: A perspective. Applied Vegetation Science, 4, 111-114.

Pugnaire, F.I., Haase, P., Puigdefábregas, J., Cueto, M., Clark, S.C., \& Incoll, L.D. (1996). Facilitation and succession under the canopy of a leguminous shrub, Retama sphaerocarpa, in a semi-arid environment in south-east Spain. Oikos,

Pugnaire, F.I., Luque, M.T., Armas, C., \& Gutiérrez, L. (2006). Colonization processes in semi-arid Mediterranean old-fields. Journal of Arid Environments, 65, 591-

Puigdefábregas, J., \& Mendizábal, T. (1998). Perspectives on desertification: western 603.

Pywell, R.F., Bullock, J.M., Roy, D.B., Warman, L.I.Z., Walker, K.J., \& Rothery, P. (2003). Plant traits as predictors of performance in ecological restoration. Journal of Applied Ecology, 40, 65-77.

Rodríguez-Echeverría, S., \& Pérez-Fernández, M.A. (2005). Potential for use of Iberian

Querejeta, J.I., Roldán, A., Albaladejo, J., \& Castillo, V. (1998). The role of mycorrhizae, site preparation, and organic amendment in the afforestation of a

Temperton, V.M., \& Zirr, K. (2004). Order of arrival and availability of safe sites - An example of their importance for plant community assembly in stressed ecosystems. Assembly rules and restoration ecology - Bridging the gap between theory and practice (pp. 285-304). Washington D.C.: Island Press. 
Valiente-Banuet, A., Vital Rumebe, A., Verdú, M., \& Callaway, R.M. (2006). Modern Quaternary plant lineages promote diversity through facilitation of ancient Tertiary lineages Proceedings of the National Academy of Sciences, 103, 1681216817.

Valladares, F., Hernández, L.G., Dobarro, I., García-Pérez, C., Sanz, R., \& Pugnaire, F.I. (2003). The ratio of leaf to total photosynthetic area influences shade survival and plastic response to light of green-stemmed leguminous shrub seedlings. Annals of Botany, 91, 577-584.

Valladares, F., Villar Salvador, P., Domínguez, S., Fernández-Pascual, M., Peñuelas, J.L., \& Pugnaire, F.I. (2002). Enhancing the early performance of the leguminous shrub Retama sphaerocarpa (L.) Boiss.: fertilisation versus Rhizobium inoculation Plant and Soil, 240, 253-262.

Vitousek, P.M., Mooney, H.A., Lubchenco, J., \& Melillo, J.M. (1997). Human domination of Earth's ecosystems. Science, 277, 494-499.

Walker, L.R., \& del Moral, R. (2003). Primary Succession and Ecosystem Rehabilitation. Cambridge: Cambridge University Press.

Wong, N.K., Dorrough, J., Hirth, J.R., Morgan, J.W., \& O'Brien, E. (2007). Ecology, 32, 617-625.

405 Young, T.P. (2000). Restoration Ecology and conservation biology. Biological Conservation, 92, 73-83. 
410 Fig.1. Sapling survival of 14 shrub and tree species with summer irrigation (solid dots)

411 and without watering (open dots) in a degraded semiarid shrubland in SE Spain. $\chi^{2}$ and

412 significance of the watering treatment (logistic regression) in autumn 2006 are shown

413 below each species name.
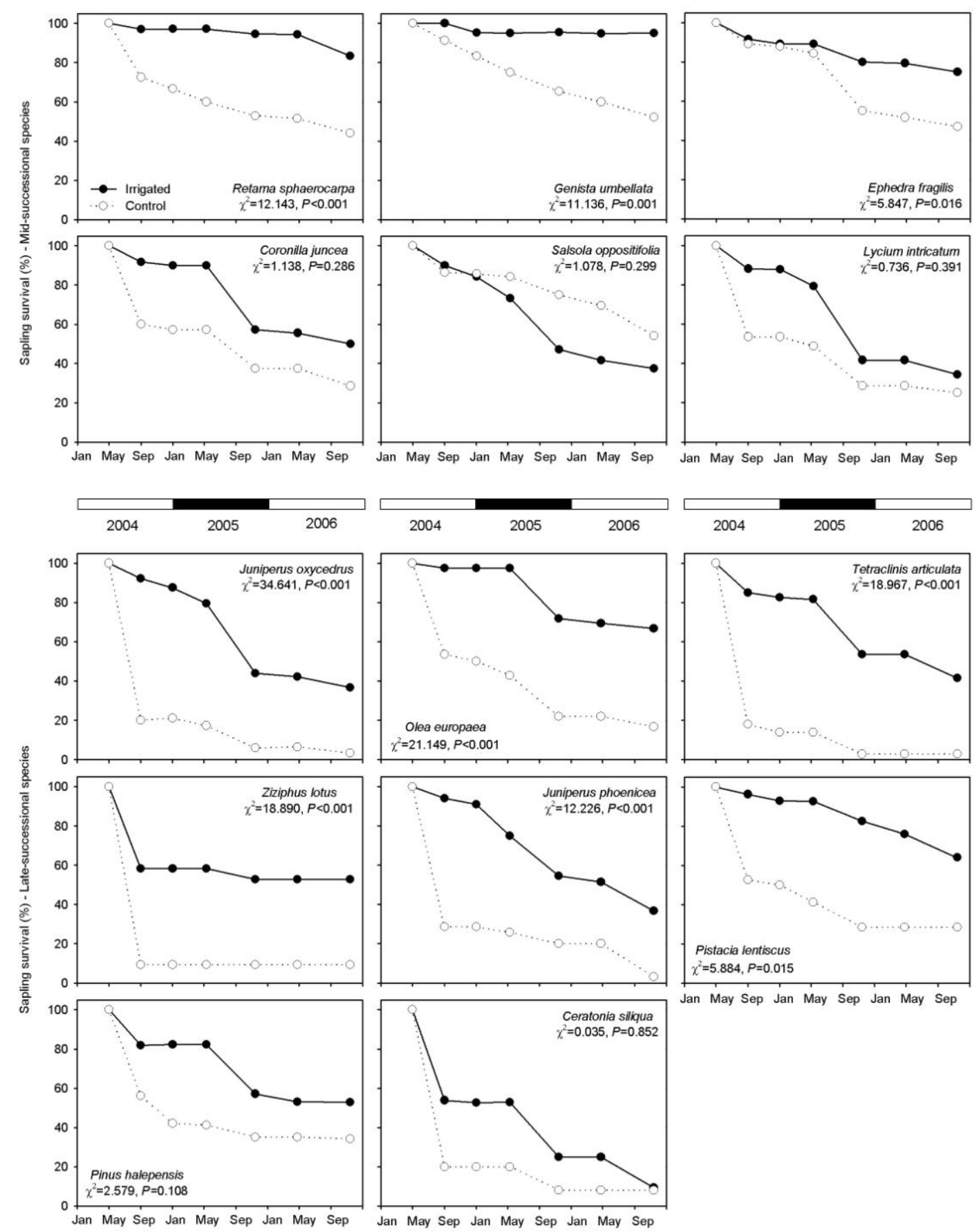


\section{Appendix A: Supplementary Material}

416 Table 1. Air temperature, soil temperature and relative air humidity in the east and

417 west-facing plot, in the experimental site, on a six-day period of summer 2004. Soil

418 temperature was measured at $5 \mathrm{~cm}$ depth (Hobo, Onset Computers, Pocasset, MA,

419 USA) and relative air humidity and air temperature at $20 \mathrm{~cm}$ height (Hobo Pro).

420

\begin{tabular}{llcc}
\hline & & East & West \\
\hline Air temperature $\left({ }^{\circ} \mathrm{C}\right)$ & Mean & $29.8 \pm 0.6$ & $30.0 \pm 0.6$ \\
& Max & $45.9 \pm 0.8$ & $46.7 \pm 0.8$ \\
& Min & $18.7 \pm 0.4$ & $19.1 \pm 0.5$ \\
\hline Soil temperature $\left({ }^{\circ} \mathrm{C}^{1}\right)$ & Mean & $35.5 \pm 0.3$ & $36.1 \pm 0.4$ \\
& Max & $46.5 \pm 0.7$ & $47.1 \pm 0.8$ \\
& Min & $26.9 \pm 0.4$ & $27.5 \pm 0.4$ \\
\hline Relative air humidity $(\%)$ & Mean & $52.7 \pm 4.6$ & $28.5 \pm 1.1$ \\
& Max & $93.6 \pm 6.0$ & $41.7 \pm 5.1$ \\
& Min & $24.1 \pm 0.1$ & $23.4 \pm 0.0$ \\
\hline
\end{tabular}

421

422 
423 Table 2. Seasonal and annual rainfall (in $\mathrm{mm}$ ) in the years 2004, 2005, and 2006, and 424 average of the 1950-2000 period in the experimental site.

425

\begin{tabular}{cccccc}
\hline \multirow{2}{*}{ Year } & \multicolumn{5}{c}{ Season } \\
\cline { 2 - 5 } & Winter & Spring & Summer & Autumn & \\
\hline 2004 & 90 & 205 & 2 & 18 & 315 \\
2005 & 73 & 35 & 6 & 30 & 145 \\
2006 & 113 & 90 & 26 & 52 & 281 \\
Average & 91 & 82 & 16 & 92 & 281 \\
\hline
\end{tabular}

426

427 
428 Fig.1. Experimental area, located in the Sierra Alhamilla range, SE Spain. In the past

429 years, intense pressure from human activities deforested the woody canopy. Recurrent

430 restoration with late-successional species resulted unsuccessful because of severe

431 drought.

432

433

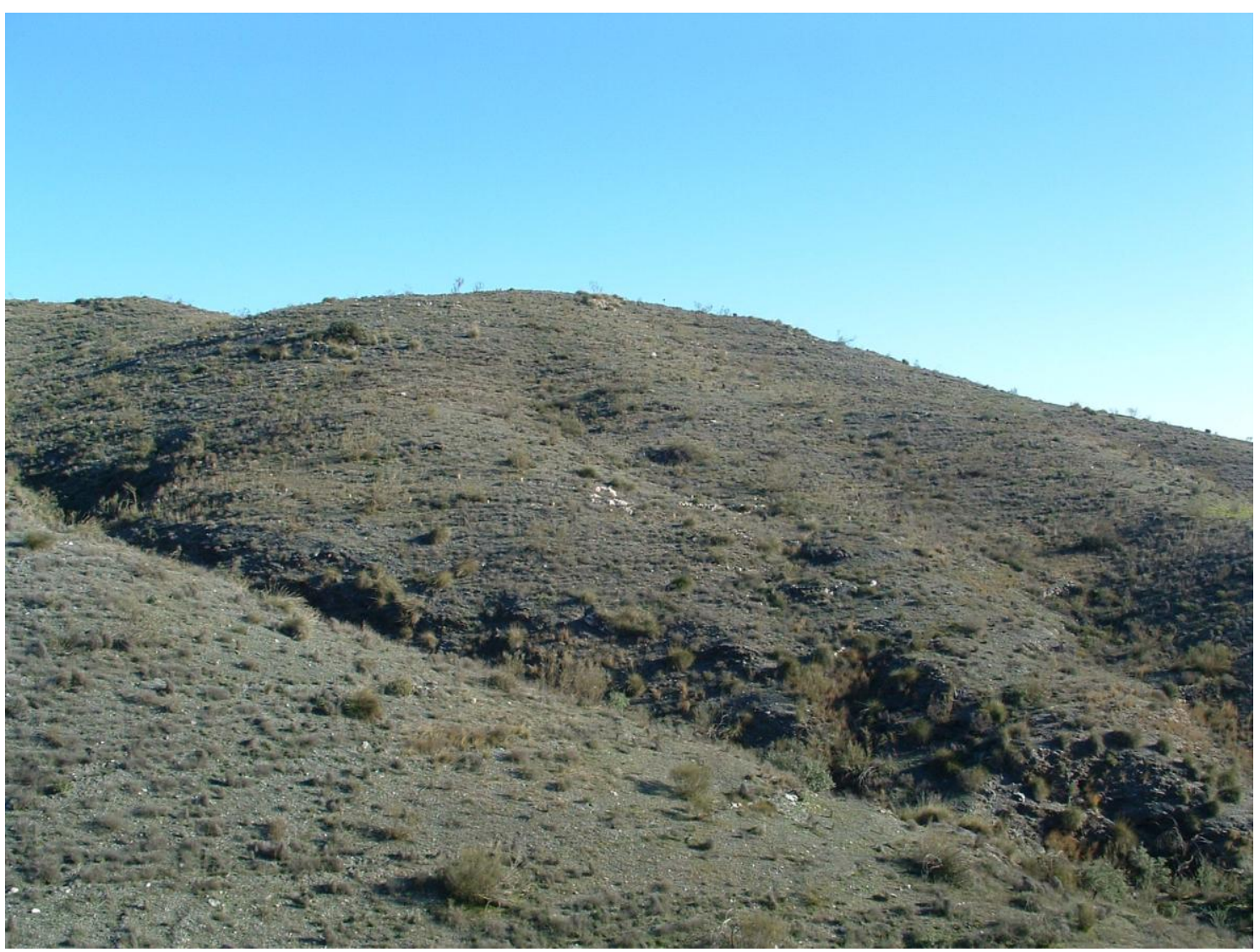

434

435 